\title{
Synthesis and Characterization of a New Cationic Surfactant Derived from 5-Chloro-1 $H$-indole-2,3-dione In Aqueous Systems
}

\author{
Z. Tribak $^{1}$, R. Ghibate ${ }^{5}$, M.K. Skalli ${ }^{1}$, Y. Kandri Rodi ${ }^{2}$, D. Mrani ${ }^{3}$, A. Aouniti ${ }^{4}$, \\ B. Hammouti ${ }^{4}$, O. Senhaji ${ }^{*}$ \\ ${ }^{1}$ Laboratory of Applied Chemistry, Sidi Mohamed Ben Abdellah University, Faculty of Science and Technology \\ of Fez, Morocco. \\ ${ }^{2}$ Laboratory of Applied Organic Chemistry, Sidi Mohamed Ben Abdellah University, Faculty of Science and \\ Technology of Fez, Morocco. \\ ${ }^{3}$ Laboratory of Analytical Chemistry, Environment and Materials(ACEM),Moulay Ismail University, Faculty of \\ Science and Technology of Erracchidia, Morocco. \\ ${ }^{4}$ LCAE-URAC18, Faculty of Science, Mohammed first University, Po Box 717, 60000 Oujda, Morocco. \\ ${ }^{5}$ Laboratory of Applied Physical Chemistry (ECPA), MoulayIsmaïl University, Faculty of Sciences and \\ Technology of Erracchidia, Morocco.
}

ABSTRACT:In this paper, anovel cationic surfactant is synthesized by the alkylation reaction of 5-Chloro$1 \mathrm{H}$-indole-2,3-dioneunder the conditions of phase transfer catalysis and quaternizationby trimethylamine in acetone solution.Chemical structures of synthesized compounds were confirmed by ${ }^{1} \mathrm{HNMR}$ and ${ }^{13} \mathrm{C}$ NMR. The micellization of cationic surfactant in aqueous solution at room temperature has been reported using the conductivity of the measurements

Keywords:5-Chloro- $1 H$-indole-2,3-dione, alkylation, quaternization, monomer, surfactants

\section{INTRODUCTION}

The particular structure of the surfactants allows them to be classified among the molecules most present in the cosmetics, pharmaceutical or agroalimentary industries [1]. The high production volumes of these industries have highlighted the need to use non-polluting surfactants, which can be synthetic or natural. This current problem has resulted in the use of agro-resources such as carbohydrates, phosphonates [2] and 5-Chloroisatin derivatives as a starting material for the synthesis of compounds with high added value.In the literature, 5-chloro- $1 H$-indole-2,3-dione is a polyvalent chemical building block capable of forming a large number of heterocyclic molecules [3]. The compound has an indole ring structure common to many pharmaceutical products. Its derivatives have exhibited activities such as antibacterial [4], antiinflammatory [5], analgesic [6], anti-viral [7], antifungal [8], anti-tubercular [9], anti-depressant [10] and anticorrosive [11]. The presence of several reaction centers in isatin and its derivatives makes them capable of participating in a large number of reactions [12].The keto group at position 2 and in particular at position 3 can be added to the $\mathrm{C}-\mathrm{O}$ bond and condensation reactions [13].Through the primary amine group, compounds of the 5Chloroisatin series are able to penetrate $\mathrm{N}$-alkylation and thereafterquaternization by trimethylamine as an example in the case of the synthesis of the novel surfactants ofindole [14].Generally, the structure of a surfactant is said to be amphiphilic, it is defined by the joint presence of a hydrophilic part and a hydrophobic part, depending on the nature of the hydrophilic part, cationic, anionic or zwitterionic surfactants may be found or nonionic surfactants [15-18]. The hydrophobic part, for its part, is most often in the form of a carbon chain of variable length, whether branched or not. It is well known that surfactant molecules are associated with micelles which begin to form above the critical micellar concentration (CMC) [19-22]. Numerous factors such as the addition of electrolytes [23-25], the $\mathrm{pH}$ of the buffer [26], the temperature [27,28], the addition of organic modifiers [29, 30] Ionic strength of the aqueous solution [31, 32], the presence of additives etc., make this value different from that determined in pure water.The determination of the CMC takes place in several ways such as the tensiometry which records the decrease in the surface tension as a function of the surfactant concentrations up to a limit beyond which the surface tension no longer decreases, and other methods used as conductivity [33-34] for charged surfactants, spectrofluorometry, nuclear magnetic resonance and UV-visible absorption spectroscopy [35-37].In the present work, we describe the synthesis of a new surfactant monomer derived from 5-Chloroisatin via the $\mathrm{N}$-alkylation method under the conditions of phase transfer catalysis followed by the quaternizationof 1- (6-bromohexyl) 5chloroindoline-2,3-dione, with trimethylamine. The 
structures of the compounds are perfectly packaged by ${ }^{1} \mathrm{H}$ NMR, ${ }^{13} \mathrm{C}$ NMR. The critical micelle concentration of our surfactant was determined in pure water at $25^{\circ} \mathrm{C}$ by a conductimeter.

\section{RESULTS AND DISCUSSION}

\section{Preparation of 1- (6-bromohexyl) -5-} chloroindoline-2,3-dione:

In order to obtain novel heterocyclic compounds having the 5-chloro- $1 \mathrm{H}$-indole-2,3-dione nucleus [38], we were interested in the condensation of 5-Chloroisatin (1)with the 1,6-dibromohexane, under the conditions of phase transfer catalysis (CTP)[39], solubilizing in N, N-dimethylformamide (DMF) in the presence of a weak base and a catalyst to promote the reaction. After purification by chromatography on a silica column with a mixture of ethyl acetate/hexane [40], the 1- (6-bromohexyl) -5chloroindoline-2,3-dione (2) compound is obtained in good yield.

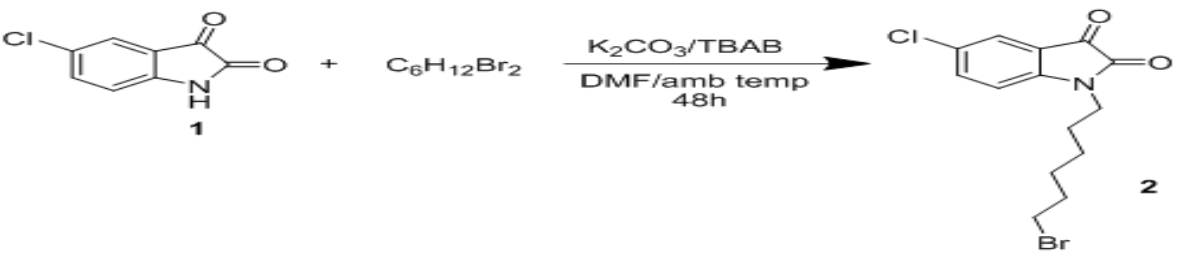

Figure 1: Synthesis of novel derivatives of 5-Chloro- $1 H$-indole-2,3-dione

\section{Quaternization of 1-
chloroindoline-2,3-dione(3):}

Quaternization of 1- (6-bromohexyl) -5chloroindoline-2,3-dione, is obtained by

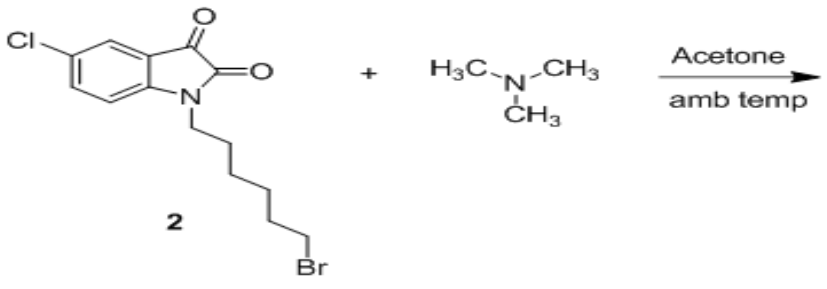

-5- trimethylamine [41] solubilized in acetone at room temperature, according to the following reaction:

Figure2: Synthesis of novel cationic surfactant.

The product obtained is purified by precipitation in diethyl ether with a yield of $95 \%$ and it's soluble in methanol and water.

\section{CMC determination:}

With the intention of estimating the $\mathrm{CMC}$ of our cationic surfactant, the conductivity plots were carried out as a function of the concentration of 5chloro-1-(6-(trimethyl- $\lambda^{4}$-azanyl)hexyl)indoline-2,3dione in an aqueous solution at room temperature[42]. Measurements for selected surfactants were carried out in pure water and at different concentrations of 5chloro-1-(6-(trimethyl- $\lambda^{4}$-azanyl)hexyl)indoline-2,3dione at $\mathrm{pH} 7.0$ and are shown in Table 1.The first corresponds to the concentration range below the $\mathrm{CMC}$, when only the surfactant monomers exist in solution [43].

At higher concentrations of surfactant, the micelles begin to form and a change in slope occurs because the conductivity increases in a different way.The intersection of these two lines is taken as the CMC value of the surfactant. Indeed, at this CMC concentration, many important properties of surfactant usually change strongly in the solution [44-47]. The critical micelle concentration was determined in pure water at $25^{\circ} \mathrm{C}$ by means of conductometer and found to be $5.10^{-3} \mathrm{M}$. The results are shown in Figure 3 .

Table1: Variation of the specific conductivity relative to the surfactant concentration for the conductivity determination of the $\mathrm{CMC}$ at $\mathrm{T}=25^{\circ} \mathrm{C}$. $(\mathrm{pH} 7.0)$

\begin{tabular}{|c|c|c|c|c|c|c|}
\hline $\mathrm{C}$ & & & & \\
$(\mathrm{M})$ & $1.2510^{-3}$ & $2.510^{-3}$ & $510^{-3}$ & $1010^{-3}$ & $13.310^{-3}$ & $2010^{-3}$ \\
\hline $\boldsymbol{\chi}$ & 91.2 & 175.2 & 350 & 652 & 875 & 1232 \\
\hline
\end{tabular}




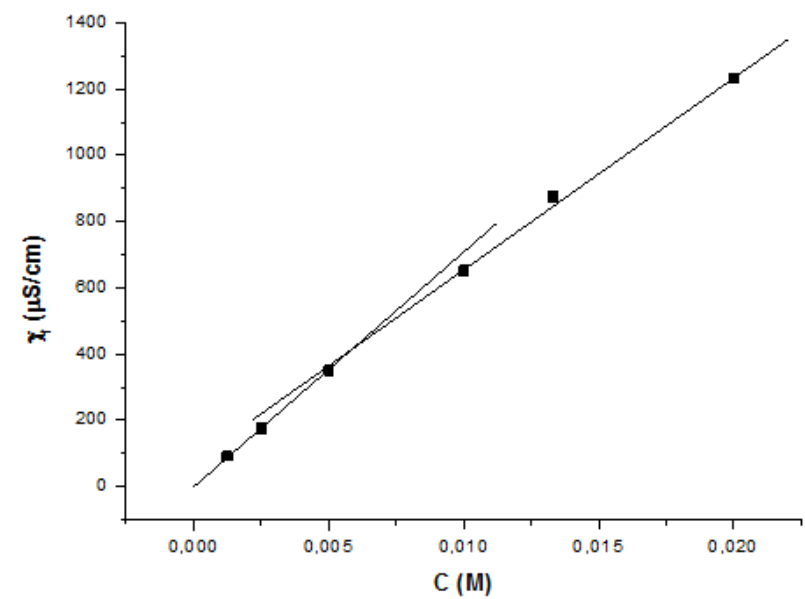

Figure 3: Variation of the conductivity of the surfactant with its concentration atambient temperature.

\section{Experimental Part:}

Melting points were determined by the Kofler bench. NMR spectra were recorded on Bruker $300 \mathrm{NMR}$ spectrometer advancement in $\mathrm{CDCl}_{3}$ using tetramethylsilane (TMS) as reference, chemical shifts are reported in parts per million of the inductive field. The coupling constants $(\mathrm{J})$ are in hertz. The following abbreviations are used to describe peak models: $s$, singlet; d, doublet; dd, double doublet; t, triplet; $\mathrm{q}$, quartet; $\mathrm{m}$, multiplet. The conductivity has been measured at $25{ }^{\circ} \mathrm{C}$ with a conductometer.

\section{Synthesis of compound 2:}

In a $100 \mathrm{ml}$ two-necked flask, to a solution of 5-Chloro- $1 H$-indole-2,3-dione $(0.4 \mathrm{~g}, 2.20 \mathrm{mmol})$ in DMF (15 ml), Potassium carbonate $(0.5 \mathrm{~g}, 3.3 \mathrm{mmol})$, a catalytic amount of tetra-n-butylammonium bromide $(0.1 \mathrm{~g}, 0.3 \mathrm{mmol})$ and the brominated reagent were added. The mixture is activated by stirring for 48 hours at $25^{\circ} \mathrm{C}$. After evaporation of the solvent and treatment of the reaction, the crude reaction product is purified by column chromatography. The new product is isolated as a powder with good yield.

\section{1- (6-bromohexyl) -5-chloroindoline-2,3-dione(2):}

Yield: $74 \% ; \mathrm{mp}: 66-70^{\circ} \mathrm{C} ; \mathrm{R}_{\mathrm{f}}=0.8 ; \mathrm{RMN}^{1} \mathrm{H}\left(\mathrm{CDCl}_{3}\right.$; $300 \mathrm{MHz}): \delta(\mathrm{ppm}) 7.68\left(\mathrm{dd}, \mathrm{H}, \mathrm{CH}_{\mathrm{Ar}}, \mathrm{J}_{\mathrm{H}-\mathrm{H}}^{4}=1.5 \mathrm{~Hz}\right.$, $\left.\mathrm{J}_{\mathrm{H}-\mathrm{H}}^{3}=4.5 \mathrm{~Hz}\right) ; 7.60\left(\mathrm{~d}, \mathrm{H}, \mathrm{CH}_{\mathrm{Ar}}, \mathrm{J}_{\mathrm{H}-\mathrm{H}}^{4}=1.5 \mathrm{~Hz}\right)$ $7.24\left(\mathrm{~d}, \mathrm{H}, \mathrm{CH}_{\mathrm{Ar}}, \mathrm{J}_{\mathrm{H}-\mathrm{H}}^{3}=6 \mathrm{~Hz}\right) ; 3.65\left(\mathrm{t}, 2 \mathrm{H}, \mathrm{CH}_{2}, \mathrm{~J}_{\mathrm{H}-\mathrm{H}}^{4}\right.$ $=3 \mathrm{~Hz}) ; 3.51\left(\mathrm{t}, 2 \mathrm{H}, \mathrm{CH}_{2}, \mathrm{~J}^{3}{ }_{\mathrm{H}-\mathrm{H}}=6 \mathrm{~Hz}\right) ; 1.73-1.82(\mathrm{~m}$, $\left.2 \mathrm{H}, \mathrm{CH}_{2}\right), 1.54-1.63\left(\mathrm{~m}, 2 \mathrm{H}, \mathrm{CH}_{2}\right), 1.38-1.46(\mathrm{~m}, 4 \mathrm{H}$, $\left.\mathrm{CH}_{2}\right) . \mathrm{RMN}^{13} \mathrm{C}\left(\mathrm{CDCl}_{3} ; 75 \mathrm{MHz}\right): \delta(\mathrm{ppm}): 182.89$ $(\mathrm{C}=\mathrm{O}) ; 158.35(\mathrm{~N}-\mathrm{C}=\mathrm{O}) ; 149.72,127.72,119.40(\mathrm{Cq})$; 137.39, 124.39, $112.88\left(\mathrm{CH}_{\mathrm{Ar}}\right) ; 35.56,32.58,27.67$, $27.00,25.72\left(\mathrm{CH}_{2}\right)$.

\section{Synthesis of compound ( $\underline{3})$ :}

In a $100 \mathrm{ml}$ single-necked flask equipped with a magnetic bar, 1 equivalent of 5-Chloroisatin derivative in $15 \mathrm{ml}$ of acetone is introduced and then 5 equivalents of trimethylamine $(45 \% \mathrm{w} / \mathrm{w})$ are added.
The mixture is stirred at room temperature; the reaction is followed by thin layer chromatography (TLC) every hour for about $24 \mathrm{~h}$. After a certain time, the total disappearance of the starting bromide is seen. At the end of the handling, the solvent is evaporated under vacuum and the mixture treated. The precipitate obtained is a slightly violet solid which is soluble in the minimum of methanol and then purified by precipitation in diethyl ether. The product is then characterized by proton NMR, and carbon NMR.

\section{5-chloro-1-(6-(trimethyl- $\lambda^{4}$-azanyl)hexyl)indoline- 2,3-dione (3):}

Yield: $88 \% ; \mathrm{mp}: \quad 100-120^{\circ} \mathrm{C} ; \quad \mathrm{R}_{\mathrm{f}}=0.6 ; \quad \mathrm{RMN} \quad{ }^{1} \mathrm{H}$ $\left(\mathrm{CDCl}_{3} ; 300 \mathrm{MHz}\right): \delta(\mathrm{ppm}) 7.35\left(\mathrm{~d}, \mathrm{H}, \mathrm{H}_{\mathrm{Ar}},{ }^{4} \mathrm{~J}_{\mathrm{H}-\mathrm{H}}=1.8\right.$ $\mathrm{Hz}) ; 7.17-7.2\left(\mathrm{dd} \mathrm{H}, \mathrm{H}_{\mathrm{Ar}},{ }^{4} \mathrm{~J}_{\mathrm{H}-\mathrm{H}}=3 \mathrm{~Hz},{ }^{3} \mathrm{~J}_{\mathrm{H}-\mathrm{H}}=9 \mathrm{~Hz}\right)$; $6.96\left(\mathrm{~d}, \mathrm{H}, \mathrm{H}_{\mathrm{Ar}},{ }^{3} \mathrm{~J}_{\mathrm{H}-\mathrm{H}}=9 \mathrm{~Hz}\right) ; 3.52-3.71\left(\mathrm{~m}, 4 \mathrm{H}, \mathrm{CH}_{2}\right)$; $3.31\left(\mathrm{t}, 2 \mathrm{H}, \mathrm{CH}_{2},{ }^{3} \mathrm{~J}_{\mathrm{H}-\mathrm{H}}=9 \mathrm{~Hz},{ }^{4} \mathrm{~J}_{\mathrm{H}-\mathrm{H}}=3 \mathrm{~Hz}\right) ; 3.15-3.25(\mathrm{~m}$, $\left.2 \mathrm{H}, \mathrm{CH}_{2}\right) ; 1.57-1.64\left(\mathrm{~m}, 4 \mathrm{H}, \mathrm{CH}_{2}\right) ; 2.97(\mathrm{~s}, 9 \mathrm{H}$, $\left.\mathrm{CH}_{3}\right) \cdot \mathrm{RMN}^{13} \mathrm{C} \quad\left(\mathrm{CDCl}_{3} ; \quad 75 \mathrm{MHz}\right): \quad \delta(\mathrm{ppm})$ $209.77(\mathrm{C}=\mathrm{O}) ; \quad 177.99(\mathrm{~N}-\mathrm{C}=\mathrm{O}) ; \quad 141.54, \quad 131.28$, $128.36(\mathrm{Cq})$; 130.03, 123.79, 111.10 $\left(\mathrm{CH}_{\mathrm{Ar}}\right)$; 26.06, 25.45, 25.05, 22.09( $\left(\mathrm{CH}_{2}\right), 29.83\left(\mathrm{CH}_{3}\right)$.

\section{CONCLUSION}

Our work was oriented on the synthesis study and the characterization of a new cationic surfactant derived from 5-Chloro-1H-indole-2,3-dione. The production of this monomer takes place in two stages, firstly the alkylation of 5-Chloroisatin with the brominated reagent under the conditions of catalysis by phase transfer and then the quaternization of 1- (6bromohexyl) -5-chloroindoline -2,3-dione, the synthesized structures were identified on the basis of the NMR spectral data. Tests of the conductimetric method in water at ambient temperature made it possible to study the behaviour of the micellization of our cationic surfactant. Conductivity is a useful technique for determining the thermodynamic parameters of the surfactant micellization. 


\section{REFERENCES}

[1]. C.A. Bunton, F. Nome, F.H. Quina, L.S. Romsted, Ion binding and reactivity at charged aqueous interfaces, Accounts Chem. Res., 24 (12), 1991, 357-364.

[2]. Fr. 2815633 (2002), Atofina-Fr, invs.: A. Riondel, R. Pirri, T. Jeanmaire; Chem. Abstr. 2002, 136, 340832m.

[3]. Z. Tribak, Y. KandriRodi, Y. Kharbach, A. Haoudi, M.K. Skalli, A. Mazzah, M. Akhazzane. E.M. Essassi., Synthesis Of New 1H-Indole-2,3-Dione Derivatives Using PhaseTransfer Catalysis And Characterization By XRay Crystallography, J. Mar. Chim. Heterocycl. 15(1), 2016, 79-84.

[4]. V. Alagarsamy, R. Revathi, S. Meena, K.V. Ramaseshu, S. Rajasekaran, E. De Clercq, AntiHIV, Antibacterial And Antifungal Activities of Some 2,3-diSubstituted Quinazolin-4(3H)-ones,Indian J. Pharm. Sci. 66 (4), 2004, 459-462.

[5]. V. Alagarsamy, S. Meena, S. Vijayakumar, K.V. Ramseshu, R. Revathi, Synthesis and Pharmacological Investigation of Some Novel 2,3-diSubstituted Quinazolin-4(3H)-Ones As Analgesic and Antiinflammatory Agents,Pharmazie,58 (4), 2003, 233-236.

[6]. S.K. Sridhar, M. Sreenivasulu, S. Ramachandran, S.K.G. Sam, M. Saravanan,Synthesis, Analgesic and Antiinflammatory activity of n-Mannich Bases of (4'-substituted)-2-Phenyl Indoles,Indian DrugsBombay, 38 (10), 2001, 531-534.

[7]. S.N. Pandeya, D. Sriram, G. Nath, E. DeClercq, Synthesis, Antibacterial, Antifungal And AntiHIV Activities of Schiff and Mannich Bases Derived From Isatin Derivatives and N-[4-(4'chlorophenyl)thiazol-2-yl]

Thiosemicarbazide,Eur. J. Pharm. Sci. 9 (1), 1999, 25-31.

[8]. R.S. Verma, W. L. Nobles, Antiviral, Antibacterial, and Antifungal Activities of Isatin N-Mannich Bases,J. Pharm. Sci. 69 (5), 1975,881-882.

[9]. T. Aboul-Fadl, FA. Bin-Jubair, Anti-Tubercular Activity of Isatin Derivatives, Int. J. Res. Pharm. Sc, 1(2), 2010, 113-126.

[10]. F.D. Popp,R. Parson, B.E. Donigan, Synthesis of potential anticonvulsants: Condensation of isatins with acetone and related ketones, $\mathrm{J}$. Pharm. Sci. 69 (10), 1980,1235-1237.

[11]. Z. Tribak, Y. Kharbach, A. Haoudi, M.K. Skalli, Y. Kandri. Rodi, M. El Azzouzi, A. Aouniti,B. Hammouti, O. Senhaji,Study of new 5-Chloro-Isatin derivatives as efficient organic inhibitors of corrosion in $1 \mathrm{M} \mathrm{HCl}$ medium:
Electrochemical and SEM studies, J. Mater. Environ. Sci. 7 (6), 2016, 2006-2020.

[12]. F.M. Da Silva, S.J. Garden, A.C. Pinto.The Chemistry of Isatins: a Review from 1975 to 1999, J. Braz. Chem. Soc,12 (3), 2001, $273-$ 324.

[13]. P.D. Popp, The Chemistry of Isatin, Adv. Hetercycl. Chem, 18, 1975, 1-58.

[14]. B.Boyer . J-P. Roque. O.Senhaji,Etude de la réaction de télomérisation d'un monomère tensioactif cationique, Macrol.Chem. Phys.,195, 1994, 129-173.

[15]. Y. Li., P. Li, J. Wang, Y. Wang, H. Yan, R.K Thomas., Odd/Even Effect in the Chain Length on the Enthalpy of Micellization of Gemini Surfactants in Aqueous Solution, Langmuir, 21 (15), 2005, 6703-6706.

[16]. G. Bai,J. Wang, Y. Wang H. Yan., Thermodynamics of Hydrophobic Interaction of Dissymmetric Gemini Surfactants in Aqueous Solutions, J. Phys. Chem. B., 106 (26), 2002,6614-6616.

[17]. N. Jiang,P. Li, Y. Wang, J.Wang, H. Yan, R.K Thomas, Micellization of Cationic Gemini Surfactants with Various Counterions and Their Interaction with DNA in Aqueous Solution, J. Phys. Chem. B, 108 (39), 2004, 15385-15391.

[18]. S.D. Wettig., X.F. Li., R.E Verrall,Thermodynamic and Aggregation Properties of Gemini Surfactants with Ethoxylated Spacers in Aqueous Solution, Langmuir, 19 (9), 2003, 3666-3670.

[19]. J.M. Rosen,Surfactant and interfacial phenomena, 3rd Edition, book,2004, 1-500.

[20]. L. Tennouga, A. Mansri, K. Medjahed, A. Chetouani, I. Warad, The micelle formation of cationic and anionic surfactants in aqueous medium: Determination of $\mathrm{CMC}$ and thermodynamic parameters at different temperatures, J. Mater. Environ. Sci. 6 (10), 2015, 2711-2716.

[21]. M.F Emerson,A. Holtzer, Hydrophobic bond in micellar systems. Effects of various additives on the stability of micelles of sodium dodecyl sulfate and of n-dodecyltrimethylammonium bromide, J. Phys. Chem., 711967 3320-3330.

[22]. J.J Galàn, A. Gonzàlez-Pérez, J.A.Seijas.,E. Uriarte, J.R. Rodrîguez,Effect of counterion on thermodynamic micellar properties of tetradecylpyridinium in aqueous solutions, ColloidPolym. Sci., 283 (4), 2005, 456-460.

[23]. M.L. Corrin, W.D. Harkins, The Effect of Salts on the Critical Concentration for the Formation of Micelles in Colloidal Electrolytes ,J. Am. Chem. Soc. 69 (3), 1947, 683-688.

[24]. I. Benito, M.A. Garc'ia, C. Monge, J.M. Saz, M.L. Marina, Spectrophotometric and 
conductimetric determination of the critical micellar concentration of sodium dodecyl sulfate and cetyltrimethylammonium bromide micellar systems modified by alcohols and salts,Colloids Surf. A: Physicochem. Eng. Aspects 125 (2-3), 1997, 221-224.

[25]. R. Zana, S. Yiv, C. Strazielle, P. Lianos, Effect of alcohol on the properties of micellar systems: I. Critical micellization concentration, micelle molecular weight and ionization degree, and solubility of alcohols in micellar solutions, J. Colloid Interf. Sci. 80 (1), 1981, 208-223.

[26]. C.E. Lin, W.C. Lin, W.C. Chiou,Migration behaviour and selectivity of dichlorophenols in micellarelectrokinetic capillary chromatography Influence of micelle concentration and buffer pH , J. Chromatogr. A, 722 (1-2), 1996, 333 343.

[27]. P. Garidel, A. Hildebrand, R. Neubert, A. Blume,Thermodynamic Characterization of Bile Salt Aggregation as a Function of Temperature and Ionic Strength Using Isothermal Titration Calorimetry, Langmuir 16 (12), 2000, 5267-5275.

[28]. M.C. Carey, D.M. Small,Micellar properties of dihydroxy and trihydroxy bile salts: Effects of counterion and temperature, J. Colloid Interf. Sci., 31 (3), 1969, 382-396.

[29]. A. NavasDíaz, F. GarcíaSánchez, A. GarcíaPareja, Cholic acid behavior in water and organic solvent: study of normal and inverted aggregates, Colloids Surf. A: Physicochem. Eng. Aspects142 (1), 1998,27-34.

[30]. J.C. Jacquier, P.L. Desb`ene, Determination of critical micelle concentration by capillary electrophoresis application to organo-saline electrolytes, J. Chromatogr. A 743 (2), 1996, 307-314.

[31]. M. F. Chaplin, Book Review:Capillary Electrophoresis, 1995, 1-244.

[32]. M.F. Emerson, A. Holtzer, On the Ionic Strength Dependence of Micelle Number, J. Phys. Chem. 69 (11), 1965, 3718-3721.

[33]. H. Nakamura, A. Sano, K. Matsuura, Determination of Critical Micelle Concentration of Anionic Surfactants by Capillary Electrophoresis Using 2Naphthalenemethanol as a Marker for Micelle Formation,Anal. Sci., 14 (2), 1998, 379-382.

[34]. M. Cipollone, P. De Maria, A. Fontana, S. Frascari, L. Gobbi, D. Spinelli, M. Tinti, Formation of micelles and liposomes from carnitineamphiphiles,Eur. J. Med.Chem. 35 (10), 2000, 903-911.

[35]. J.C. Jacquier, P.L. Desb`ene, Determination of critical micelle concentration by capillary electrophoresis. Theoreticalapproach and validation,J. Chromatogr., A, 718 (1), 1995, 167-175.

[36]. A. Cifuentes, J.L. Bernal, J. DiezMasa,Determination of Critical Micelle Concentration Values Using Capillary Electrophoresis Instrumentation,Anal. Chem., 69 (20), 1997, 4271-4274.

[37]. C.E. Lin,Determination of critical micelle concentration of surfactants by capillary electrophoresis,J. Chromatogr. A. 1037 (1-2), 2004, 467-478.

[38]. Z. Tribak, Y. Kandri. Rodi, A. Haoudi, E.M. Essassi, F. Capet, H. Zouihri,1-Allyl-5chloroindoline-2,3-dione,IUCrData1(6),2016, $\mathrm{x} 160862$.

[39]. Z. Tribak, Y. Kandri. Rodi, A. Haoudi, E.M. Essassi, F. Capet, H. Zouihri, 1-(12-Bromododecyl)-5-chloroindoline-2,3-dione,IUCrData, 1(6), 2016, x160971.

[40]. Z. Tribak, Y. Kandr.iRodi, A. Haoudi, E. M. Essassi, F. Capet, H. Zouihri, 1-Benzyl-5chloroindoline-2,3-dione,IUCrData, 1(6), 2016,x160854.

[41]. K. Mohlin, P. Karlsson, K. Holmberg, Use of cleavable surfactants for alkyl ketene dimmer (AKD) dispersions.ColloidsSurf.A,274, 2006, 200-210.

[42]. P. Mosae. Selvakumar, E. Suresh, P.S. Subramanian, Hydrogen bonded helices: synthesis, crystal structure and self-assembled microtubes.J. Mol. Struct.,919(1-3), 2009, 7278 .

[43]. M. Wilhelm, Z.Cheng-Le, W.Yongcai,X. Renliang, M.A. Winnik.J.-L, Mura, G. Riess, M. D. Croucher,Poly(styrene-ethylene oxide) block copolymer micelle formation in water : a fluorescence probe study , Macromolecules,20(5), 1991,1033-1040

[44]. P. Wydro, M. Paluch, A study of the interaction of dodecyl sulfobetaine with cationic and anionic surfactant in mixed micelles and monolayers at the air/water interface.J. Colloid Interface Sci.,286(1), 2005, 387-391.

[45]. A. Halide, B. Çigdem,Micellization of dodecylpyridinium chloride in water-ethanol solutions,Colloid. J. 70(2), 2008, 127-133.

[46]. J. Del Castill, M.J. Suarez-Filloy, A. Castedo, T. Svitova, J.R. Rodriguez,Some Physicochemical Properties of TTAB-Butanol Micellar Aqueous Solutions,J. Phys. Chem. B.101(15), 1997, 2782-2785.

[47]. A. Dominguez, A. Fernandez, N. Gonzalez, E. Iglesias, L. Montenegro, Determination of Critical Micelle Concentration of Some Surfactants by Three Techniques, J. Chem. Educ.,74 (10), 1997, 1227. 